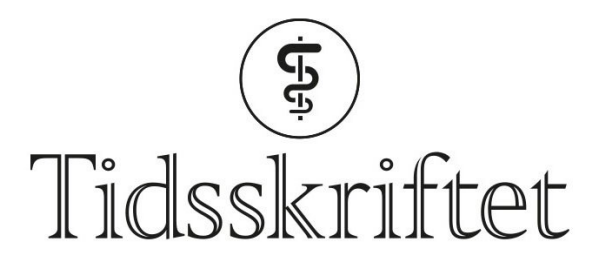

DEN NORSKE LEGEFORENING

\title{
Komplikasjoner etter ulik tilgang ved hofteproteseoperasjon
}

FRA ANDRE TIDSSKRIFTER

PETTER MORTEN PETTERSEN

Tidsskriftet

Fremre tilgang ved total hofteprotese ga flere postoperative komplikasjoner enn bakre og lateral tilgang i ny studie.

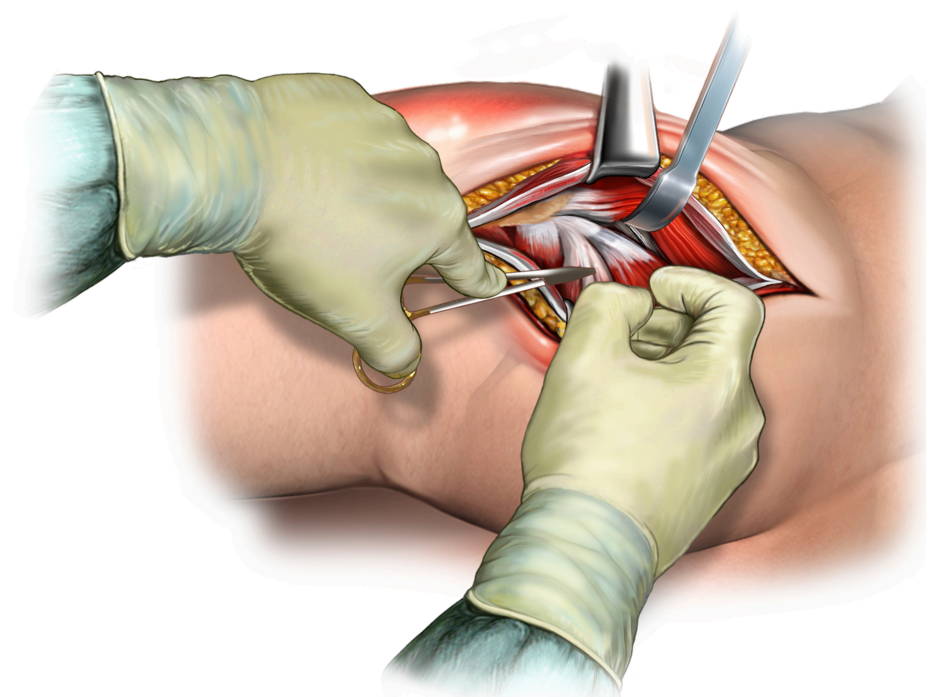

Illustrasjon: Science photo library / NTB Scanpix

Ved hofteprotesekirurgi benyttes fremre, lateral eller bakre tilgang, og praksis varierer mye mellom sykehus.

Forekomsten av kirurgiske komplikasjoner ved de tre operasjonsmetodene er nylig kartlagt i en stor retrospektiv studie med rundt 30 ooo pasienter ved sykehus i Canada (1). Rundt $10 \%$ ble operert med fremre, $70 \%$ med lateral og $20 \%$ med bakre tilgang. Pasientene ble fulgt i ett år etter operasjonen.

Etter matching for tilbøyelighetsskår (propensity score) hadde pasientene som ble operert med fremre tilgang, dobbelt så mange komplikasjoner som pasientene som ble operert med lateral eller bakre tilgang - henholdsvis $2 \%$ og $1 \%$ - til tross for at den førstnevnte gruppen besto av noe yngre og i mindre grad overvektige pasienter som sjeldnere hadde diabetes og høyt blodtrykk, og som oftere ble operert av kirurger med høyt operasjonsvolum. De hyppigste komplikasjonene var infeksjon og luksasjon. 
- Den høye komplikasjonsraten ved fremre tilgang kan muligens skyldes at kirurgene, selv om de ble klassifisert som «høyvolumkirurger», ikke hadde nok erfaring med metoden, sier Jan-Erik Gjertsen, som er førsteamanuensis og overlege ved Haukeland universitetssjukehus og leder for Nasjonalt hoftebruddregister. I studien fremkommer det ikke klart om det med fremre tilgang menes det som i Norge betegnes som fremre tilgang, dvs. mellom musculus sartorius og $m$. tensor fasciae latae, eller anterolateral tilgang, dvs. mellom $m$. tensor fasciae latae og m. gluteus medius, men Gjertsen antar at forfatterne mener det første.

- Lateral tilgang har tradisjonelt vært den mest brukte metoden i Norge, men de senere år er bakre og fremre tilgang stadig hyppigere brukt, sier Gjertsen. Tall fra Nasjonalt register for leddproteser viser at omtrent 9 ooo norske pasienter har fått innsatt total hofteprotese de senere år, hvorav rundt 70 \% med bakre tilgang.

- Fremre tilgang er lite i bruk i Norge, men kirurger ved enkelte sykehus bruker denne metoden. Disse sykehusene har gode rutiner for kvalitetssikring av behandlingen og god oppfølging av disse pasientene. Dette sikrer et tilstrekkelig pasientvolum og en god læringskurve, og vil redusere risiko for komplikasjoner og reoperasjoner, tror Gjertsen.

\section{LITTERATUR:}

1. Pincus D, Jenkinson R, Paterson M et al. Association between surgical approach and major surgical complications in patients undergoing total hip arthroplasty. JAMA 2020; 323: 1070-6.

[PubMed][CrossRef]

Publisert: 4. juni 2020. Tidsskr Nor Legeforen. DOI: 10.4045/tidsskr.20.0368

(C) Tidsskrift for Den norske legeforening 2020. Lastet ned fra tidsskriftet.no 